\title{
LOSSES INCURRED IN SOYBEAN DEPENDING ON THE WATER CONTENT AT GRAINS HARVEST
}

\author{
Fernando Shintate Galindo ${ }^{1}$, João Luis Zocoler ${ }^{1}$, Marcelo Carvalho Minhoto Teixeira Filho ${ }^{1}$,
} Salatiér Buzetti ${ }^{1}$; José Mateus Kondo Santini ${ }^{1}$; Eduardo Henrique Marcandalli Boleta ${ }^{1}$; Mariana

Gaioto Ziolkowski Ludkiewicz ${ }^{1}$

\begin{abstract}
${ }^{1}$ Universidade Estadual Paulista Júlio de Mesquita Filho (UNESP). E-mail: fs.galindo@bol.com.br; zocoler@agr.feis.unesp.br; mcmtf@yahoo.com.br; sbuzetti@agr.feis.unesp.br; santinijmk@gmail.com; eduardomarcandalli7@gmail.com; mariana.gaioto@gmail.com
\end{abstract}

\section{ABSTRACT}

The objective of this study was to evaluate the ideal water content of grains at harvest for soybean crop, yield and production components as well as losses from natural drying in the field at different water contents at grains harvest. The experimental design was in randomized blocks with 4 repetitions and the treatments consisted in the harvest of the following average levels of water contents of grains on a wet basis: 37.9 (point of full physiological maturity), 20.2, 18.7, 15.6, 14.4, and $13.1 \%$. The final population of plants, 100 grains weight and potential yield of grains linearly decreased with the reduction of grain moisture content at harvest, however, due to the injuries and difficulty of separating the grains from the legume, the anticipation of the soybean harvest causes higher losses, with ideal harvesting point close to $13 \%$ moisture (W.B.).

Keywords: Glycine max, grain humidity for harvest, grains productivity, yield components

\section{PERDAS OCORRIDAS NA CULTURA DA SOJA EM FUNÇÃO DO TEOR DE ÁGUA DOS GRÃOS NA COLHEITA}

\section{RESUMO}

Objetivou-se estudar o teor de água ideal dos grãos na colheita da cultura da soja, a produtividade e os componentes produtivos, bem como as perdas com a secagem natural em campo com diferentes teores de água dos grãos na colheita. O delineamento experimental foi em blocos ao acaso com quatro repetições e os tratamentos consistiram na colheita nos seguintes teores de 
água em base úmida (b.u.) dos grãos: 37,9 (ponto de maturidade fisiológica plena), 20,2; 18,7; 15,$6 ; 14,4 ;$ e $13,1 \%$. A população final de plantas, massa de 100 grãos e produtividade potencial de grãos decresceram linearmente com a redução do teor de água dos grãos na colheita, entretanto, devido aos danos e dificuldade de separar os grãos dos legumes, a antecipação da colheita da soja faz com que as perdas sejam mais elevadas, com ponto de colheita ideal próximos dos 13\% de umidade (b.u.).

Palavras-chave: Glycine max, umidade do grão para colheita, produtividade de grãos, componentes de produção

\section{INTRODUCTION}

In 2014/2015 harvest, soybean cultivation occupied an area of 31,57 million hectares in Brazil, with an average grain yield of 3,011 $\mathrm{kg} \mathrm{ha}^{-1}$, being the main annual crop in planted area, and marketing value (CONAB, 2015). Soybean is the main plant source of protein, an essential component of animal feed production, as well as increasing use in human nutrition (IGNÁCIO et al., 2015).

According to Toledo et al. (2008) and Figueiredo et al. (2013), grain harvesting is considered by many to be one of the most important steps within the production system, due to its direct relationship with yield and final product quality. In this way, it is essential to take care during this stage, such as the training of operators, optimum regulation of the harvester and, especially, to start harvesting with a water content in the grains that aligns a minimum quantitative and qualitative loss with the good performance of the harvest.

The physiological maturity point would be the ideal time for harvesting, since it is at this phenological stage that soybean grains present the highest quality and accumulation of dry mass and reduced incidence of pathogens (MARQUES et al., 2011, SCHUH et al.,2011, WEINBERG et al., 2008), without considering that the delay at harvesting also promotes nutritional and quantitative grain losses (WEINBERG et al., 2008).

The period between physiological maturity and grain harvest is critical because the grains remain attached to the plant and exposed to the action of biotic and abiotic factors. The losses begin before harvesting due to natural dehiscence, pests, fruit drop, and plant tipping, being more 
accentuated the longer the harvest delay and the lower the grain water content (TEFERA et al., 2011).

However, at this stage, soybean grains still have a high water content, around 40\%, depending on the genotype used, which would make it difficult to harvest mechanized due to the excess of green and moist parts of the plants, resulting in severe injuries (ALENCAR et al., 2009), as well as greater difficulty in maintaining the quality of the grains to be stored as a function of the physiological quality (ALENCAR et al., 2009; SMANIOTTO et al., 2014). According to Holtz \& Reis (2013), for lower losses and damages to seeds, the grain water content ideal for mechanized soybean harvest is between 12 and $14 \%$ and, according to the authors, total losses of soybean grains during the harvesting process increase with the time spent in the field.

Currently, climatic instability and excessive rainfall during soybean harvest can cause high losses to farmers, delaying harvesting and increasing losses. In this way, it would be interesting to define, in a simple and fast way, the best time to harvest the soybean crop, with a view to anticipating or delaying the process to assist the rural producer's decision making.

However, the literature is scarce in relation to the effects of anticipation and or delay of the grain harvest season with natural drying on grain yield. The objective of this study was to evaluate the ideal water content of the soybean grains for the harvest, evaluating the productivity and the productive components, as well as the losses with the natural drying in the field with different levels of water content for the harvest.

\section{MATERIAL E METHODS}

The study was conducted in the experimental area belonging to the College of Engineering - UNESP, located in Selvíria - state of Mato Grosso do Sul, Brazil, with geographic coordinates $20^{\circ} 22$ 'South latitude, $51^{\circ} 22^{\prime}$ West longitude and $335 \mathrm{~m}$ altitude. The soil of the experimental area was classified as an Oxisol (Latossolo Vermelho distrófico), with clayed texture, according to Embrapa classification (2013), which was cultivated by annual crops for more than 27 years, being in the last 10 years under no-tillage system and the previous cultivation with wheat crop. The climatic type in the region is Aw, according to Köppen, characterized as humid tropical with a rainy season in summer and dry in winter. The climatic data recorded during the experimental period were recorded (Figure 1). 


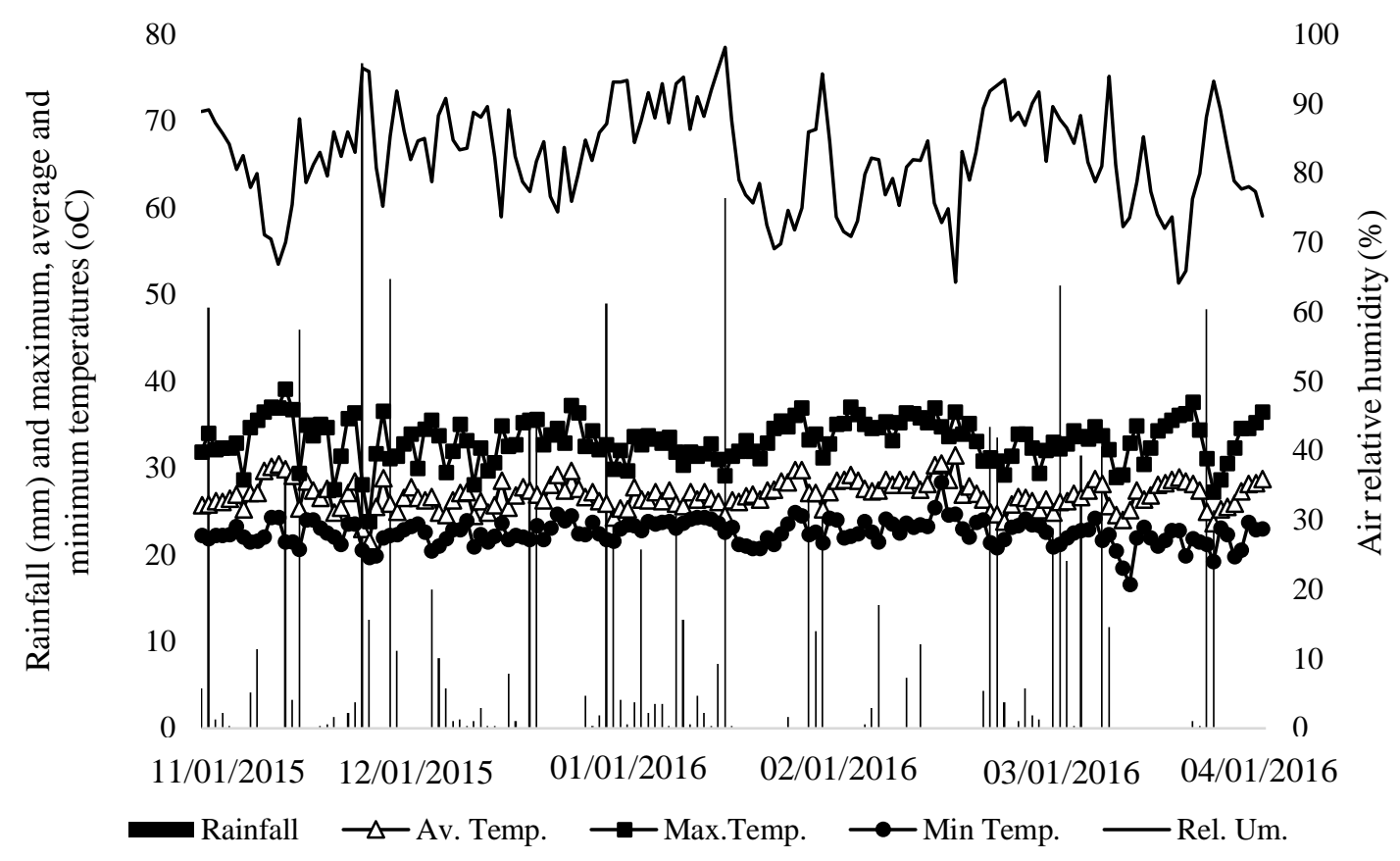

Figure 1. Rainfall, air relative humidity and maximum, average and minimum temperatures obtained from the weather station located in the Education and Research Farm of FE / UNESP during the soybean cultivation in the period of november/2015 to april/2016.

The experimental design was a randomized complete block design with six treatments and four replications. The treatments consisted of harvesting the following moisture $(\mathrm{wb})$ of the grains: 37.9 (physiological maturity point), 20.2, 18.7, 15.6, 14.4, and 13.1\%. The collection of each treatment occurred, respectively, on 03/03/2016, 03/07/2016, 03/11/2016, 03/14/2016, 03/18/2016, and 03/24/2016, the equivalent of 104, 110,114, 117, 121, and 127 days after emergence of soybean. The plots of the experiment were $6 \mathrm{~m}$ in length with six rows of soybean plants spaced $0.45 \mathrm{~m}$, with plot area the four central lines, excluding $0.5 \mathrm{~m}$ from the ends.

The chemical attributes of the soil in the arable layer determined before the installation of the experiment, according to methodology proposed by Raij et al. (2001), presented the following results: $10 \mathrm{mg} \mathrm{dm}^{-3}$ of P (resin); $5 \mathrm{mg} \mathrm{dm}^{-3}$ of S-SO $422 \mathrm{~g} \mathrm{dm}^{-3}$ M.O.; $5.3 \mathrm{pH}\left(\mathrm{CaCl}_{2}\right) ; \mathrm{K}, \mathrm{Ca}, \mathrm{Mg}$, $\mathrm{H}+\mathrm{Al}=2.4 ; 21.0 ; 18.0$, and $28.0 \mathrm{mmol}_{\mathrm{c}} \mathrm{dm}^{-3}$, respectively; $\mathrm{Cu}, \mathrm{Fe}, \mathrm{Mn}, \mathrm{Zn}(\mathrm{DTPA})=3.2 ; 22.0$; 24.2; and $1.2 \mathrm{mg} \mathrm{dm}^{-3}$, respectively; $0.16 \mathrm{mg} \mathrm{dm}^{-3} \mathrm{~B}$ (hot water) and $60 \%$ base saturation. Based on the soil analysis and the fertilization recommendation of the soybean crop (AMBROSANO et al., 1997), sowing fertilization was performed in the sowing furrow with $80 \mathrm{~kg} \mathrm{ha}^{-1}$ of $\mathrm{P}_{2} \mathrm{O}_{5}$ and 80 $\mathrm{kg} \mathrm{ha}^{-1}$ of $\mathrm{K}_{2} \mathrm{O}$. The seeds were treated with the fungicides Carbendazim + Thiram at a dosage of 
$30+70 \mathrm{~g}$ ai per $100 \mathrm{~kg}$ of seeds, respectively. The inoculation with rhizobia was carried out at a dose of $200 \mathrm{~mL} \mathrm{ha}{ }^{-1}$ (strains: SEMIA 5019 (Bradyrhizobium elkanii) and SEMIA 5079 (Bradyrhizobium japonicum), with a guarantee of $5 \times 10^{9}$ viable cells per $\mathrm{mL}$ ) with the aid of a clean mixer for incorporation and was carried out after drying the seeds after the treatment with pesticides and one hour before sowing. The experiment was implemented in November 2015, with the sowing of the soybean cultivar BMX Potência RR, planting 16 seeds per meter.

The area was irrigated by a central pivot type sprinkler system, with a mean water depth of $13 \mathrm{~mm}$ and irrigation time of approximately 36 hours, due to the need for irrigation. The harvesting was done manually, however immediately after harvesting, the treatments were evaluated and mechanically tracked in order to simulate the mechanized harvest, without the removal of the grains that remained in the pods, being recorded as loss.

The plants were measured in the 4 rows of the useful area of each plot, and the following evaluations were carried out: i) Final population of plants, determined according to the manual count; ii) Number of legume per plant; iii) Grains per legume; and iv) Grains per plant, by counting legumes and grains of 10 plants per experimental plot, when each treatment is harvested; v) 100 grain mass, determined on a precision scale of $0.01 \mathrm{~g}$, at $13 \%$ (wet basis); and vi) Grain yield and (vii) Potential grain yield, estimated as a function of number of grains per plant, mass of 100 grains and final population of plants per hectare with the following calculation: Grain mass per plant $\mathrm{x}$ final population of plants ha ${ }^{-1}$, where mass of grains $=$ number of grains per plant $\mathrm{x} 100$ grains mass / 100. After the mechanical track, the grains were quantified and the data transformed in $\mathrm{kg} \mathrm{ha}^{-1}$ to $13 \%$ water content. The results of the evaluated variables were submitted to analysis of variance (F test) and polynomial regression according to the different levels of water content of the grains at harvest.

\section{RESULTS AND DISCUSSION}

The observed results of the experiment, with coefficients of variation and significance levels of the regressions are presented (Table 1). It was verified that the longer the culture was exposed in the field after the physiological maturation, which was promoting the gradual reduction of the water content of the grains for the harvest, the greater the tendency to be caused by the biotic and abiotic factors, of bird attacks, insects and pests, climatic variations, degrana, opening of pods, and lodging of plants. This had an effect on the final population of plants, mass of 100 grains and 
potential grain yield. It is worth mentioning that, although in some lower levels of water content of the grains at harvest time the observed values were higher than those observed in water levels of the higher grains, this fact was attributed only to mere sample or chance variability.

Table 1. Final plants population, number of legume per plant, grains per legume and grains per plant,100 grains mass, grain yield (mensured) and potencial grain yield in function of water content of grains at harvest. Selvíria -MS, 2016

\begin{tabular}{|c|c|c|c|c|c|c|c|}
\hline $\begin{array}{l}\text { Water content } \\
\text { of grains at } \\
\text { harvest } \\
\text { (\% w.b.) }\end{array}$ & $\begin{array}{c}\text { Final } \\
\text { population } \\
\left(\text { Plants } \mathrm{m}^{-1}\right)\end{array}$ & $\begin{array}{c}\mathrm{N}^{\mathrm{o}} \text { of } \\
\text { legume } \\
\text { per plant }\end{array}$ & $\begin{array}{l}\mathrm{N}^{\mathrm{o}} \text { of grains } \\
\text { per legume }\end{array}$ & $\begin{array}{c}\mathrm{N}^{\mathrm{o}} \text { of } \\
\text { grains per } \\
\text { plant }\end{array}$ & $\begin{array}{l}100 \\
\text { grains } \\
\text { mass } \\
(\mathrm{g})\end{array}$ & $\begin{array}{c}\text { Grain } \\
\text { yield } \\
\left(\mathrm{kg} \mathrm{ha}^{-1}\right)\end{array}$ & $\begin{array}{c}\text { Potencial } \\
\text { grain } \\
\text { yield } \\
\left(\mathrm{kg} \mathrm{ha}^{-1}\right)\end{array}$ \\
\hline 37.9 & 15.5 & 66.9 & 3.0 & 201.1 & 17.3 & 4194 & 8736 \\
\hline 20.2 & 14.3 & 63.3 & 2.7 & 170.4 & 16.3 & 4345 & 7549 \\
\hline 18.7 & 13.4 & 67.9 & 2.7 & 183.9 & 15.6 & 4361 & 7330 \\
\hline 15.6 & 11.5 & 57.9 & 2.7 & 157.3 & 15.2 & 4508 & 7171 \\
\hline 14.4 & 14.6 & 72.5 & 2.9 & 210.4 & 15.7 & 4546 & 7385 \\
\hline 13.1 & 13.3 & 52.4 & 2.8 & 145.6 & 16.3 & 4603 & 6539 \\
\hline Overall mean & 13.8 & 63.5 & 2.8 & 178.1 & 16.1 & 4426 & 7452 \\
\hline C.V. $(\%)$ & 6.3 & 18.4 & 6.5 & 19.8 & 5.6 & 6.0 & 8.0 \\
\hline \multicolumn{8}{|l|}{ F test } \\
\hline $\mathrm{U}$ & $10.281^{* *}$ & $1.561^{\mathrm{ns}}$ & $1.959^{\mathrm{ns}}$ & $2.033^{\mathrm{ns}}$ & $8.530^{*}$ & $5.122^{*}$ & $5.850^{* *}$ \\
\hline
\end{tabular}

* Significant at 0.05 probability by $\mathrm{F}$ test; ** significant at 0.01 probability by $\mathrm{F}$ test; Ns: not significant

On the other hand, in the case of observed grain yield (measured), harvest anticipation resulted in higher losses, with reductions of 403.33; 258.21; 241.71; 94.81; and $57.26 \mathrm{~kg} \mathrm{ha}^{-1}$ of the grain harvest at the physiological maturity point up to $13.1 \%$ moisture (w.b.), reduction equivalent to $8.9 ; 5.6 ; 5.3 ; 2.1$; and $1.2 \%$, respectively. Similarly, Holtz \& Reis (2013), recommend that for lower losses and damages to seeds, the ideal grain water content for mechanized soybean harvest is between 12 and 14\% and, according to the authors, total losses of soybeans during the harvesting process increase with the time spent in the field. Schanoski et al. (2011), cite lower losses when the grains present water content around $14.5 \%$. 
According to Magalhães et al. (2009) and Schanoski et al. (2011), it can occur around 12\% of losses caused by trail mechanisms, separation and mechanical cleaning and around 3\% caused by natural dehiscence, values higher than those verified in the present study, taking into account that all treatment was mechanically traversed and suffered from environmental factors.

Considering the water content of the grains as an independent variable, adjusted regressions were significant and linearly increasing for final plant population, 100 grain mass and potential grain yield, and linear regression for grain yield as can be observed in Figures 2A, 2B, 2C, and 2D. Using the regressions, the physical and percentage reductions of the final population of plants per hectare, number of ears per hectare, grain yield and potential grain yield, water content from 37.9 to $13 \%$, with values of 2.33 plants $\mathrm{m}^{-1}(15.1 \%), 1.36$ grams $(8.0 \%),-312.59 \mathrm{~kg} \mathrm{ha}^{-1}(-7.4 \%)$ and $1832.62 \mathrm{~kg} \mathrm{ha}^{-1}(20.9 \%)$, respectively (Table 2$)$.

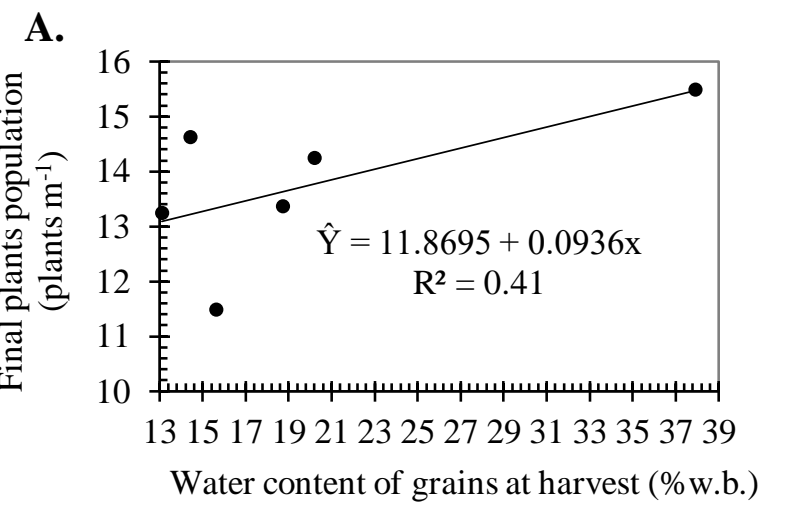

C.

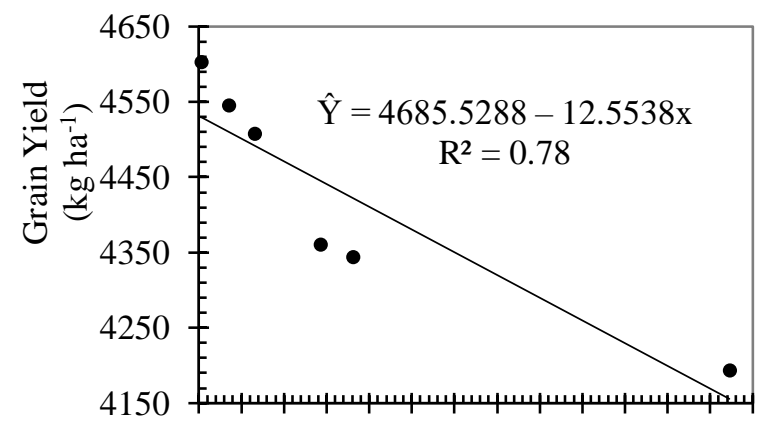

1315171921232527293133353739

Water content of grains at harvest (\%w.b.)

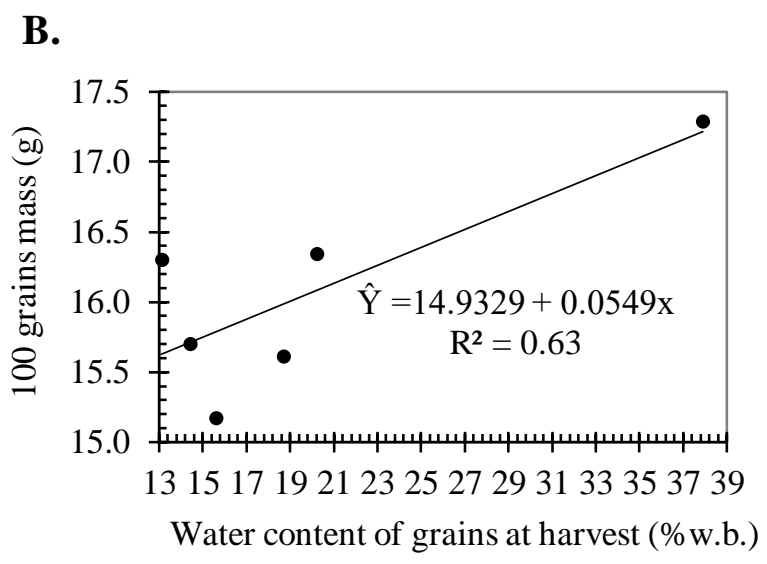

D.

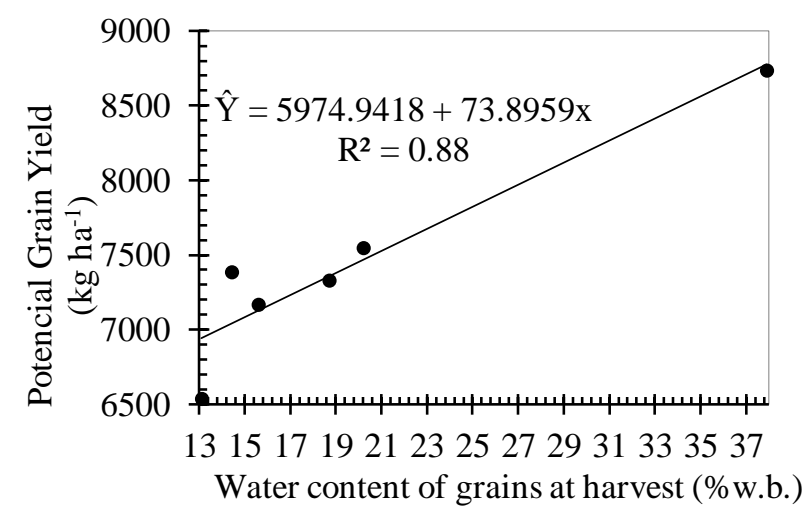

Figure 2. Final plant population (A); 100 grains mass (B), Soybean grain yield (mensured) (C); and Potencial grain yield (D) as function of water content of grans at harvest. SelvíriaMS, 2016. 
Table 2. Estimate of the final population of plants, 100 grains mass, soybean grain yield (measured) and potential grain yield as a function of the water content of the grains at harvest, due to the longer residence time of the crop in the field (natural drying), Using the regressions obtained (Figure 2) and taking as reference the water content of 37.9\%. Selvíria - MS, 2016

\begin{tabular}{ccccc}
\hline $\begin{array}{c}\text { Water content } \\
\text { of grains at } \\
\text { harvest (\%) }\end{array}$ & $\begin{array}{c}\text { Final population } \\
\text { of plants per m and } \\
\text { in percentage }\end{array}$ & $\begin{array}{c}100 \text { grains mas in g } \\
\text { and in percentage }\end{array}$ & $\begin{array}{c}\text { Grain yield in ha } \\
\text { and percentage }\end{array}$ & $\begin{array}{c}\text { Potential grain yield } \\
\text { in ha and percentage }\end{array}$ \\
\hline 37.9 & $15.42(100)$ & $17.01(100)$ & $4,209.74(100)$ & $8,775.60(100)$ \\
30.0 & $14.68(95.2)$ & $16.58(97.5)$ & $4,308.91(102.4)$ & $8,191.81(93.3)$ \\
20.2 & $13.76(89.3)$ & $16.04(94.3)$ & $4,431.94(105.3)$ & $7,467.64(85.1)$ \\
18.7 & $13.62(88.3)$ & $15.96(93.8)$ & $4,450.77(105.7)$ & $7,356.80(83.8)$ \\
15.6 & $13.33(86.5)$ & $15.79(92.8)$ & $4,489.69(106.7)$ & $7,127.72(81.2)$ \\
14.4 & $13.22(85.7)$ & $15.72(92.4)$ & $4,504.75(107.0)$ & $7,039.04(80.2)$ \\
13.1 & $13.10(84.9)$ & $15.65(92.0)$ & $4,521.07(107.4)$ & $6,942.98(79.1)$ \\
13.0 & $13.09(84.9)$ & $15.65(92.0)$ & $4,522.33(107.4)$ & $6,942.98(79.1)$ \\
\hline
\end{tabular}

The anticipation of harvest, that is, harvesting with higher water content in grains, possibly managed to mitigate the environmental effect incident to the population of soybean plants, 100 grains mass, occurring less lodging and breaking of plants, as well as losses caused by the insects, birds and feeding by other wild animals, reflecting the potential yield, which was higher when the water content of the grains was close to the point of physiological maturity, decreasing as the water content decreased in relation to this.

The results obtained corroborate with Marques et al. (2011), Schuh et al. (2011) and Di Domenico et al. (2015), who predict that the physiological maturity point would be the phenological stage in which the soybean grains present the highest quality and accumulation of dry mass and reduced incidence of pathogens, once in this phenological stage the maximum values were obtained in population of plants and 100 grains mass, however, the reduction of the yield obtained (measured) due to the high water content, is due to the difficulty of threshing of the pods and grains and cleaning, causing them injuries by kneading and losses with retained grains in the pods and plant, corroborating with Holtz \& Reis (2013), who report that in the harvest the grains 
are susceptible to damages, immediate or latent, because the damage can be presented at the time of harvest or in future consequences for the storage and sowing. Both immediate and latent mechanical damage originates at the time of threshing, when considerable forces are applied to the seeds in order to separate them from the pods, mainly because of impacts from the track cylinder. Therefore, the interpretation is that there was no reduction in crop yield at the highest moisture levels at harvest, but rather higher losses due to the absence of a harvesting mechanism that would allow it to be done under these circumstances without suffering from injuries and difficulty of separation of grains. It is worth noting that in the present work, although the harvest was done manually, immediately after harvest, the experimental plots were mechanically treaded.

Another aspect to be taken into consideration in the early harvest of grains, after physiological maturity and grain water content of more than $22 \%$, is related to high transportation and drying costs, as well as the lack of drying and storage structures close to the site of production, according to Gottardo \& Cestari Jr. (2008), which would make it impractical to anticipate the harvest of the soybean crop as a function of very high water contents in grains.

\section{CONCLUSIONS}

The final population of plants, 100 grains mass and potential grain yield decrease linearly with the reduction of water content of grains at harvest due mainly to the greater exposure of the crop to the biotic and abiotic factors.

Although the potential yield decreases as the water content of the grains decreases, due to the injuries and difficulty of separating the beans from the legume, it is recommended to harvest grains with water content close to $13 \%$, to obtain the higher soybean yield.

\section{REFERENCES}

ALENCAR, E. R. de; FARONI, L. R. D.; LACERDA FILHO, A. F.de; PETERNELLI, L. A.; COSTA, A. L. 2009. Qualidade dos grãos de soja armazenamentos em diferentes condições. Revista Brasileira de Engenharia Agrícola e Ambiental, Campina Grande, v.13, n.5, p.606613.

AMBROSANO, E. J.; TANAKA, R. T.; MASCARENHAS, H. A. A.; RAIJ, B. Van; QUAGGIO, J. A.; CANTARELlA, H. 1997. Leguminosas e oleaginosas. In: RAIJ, B. Van; CANTARELlA, H.; QUAGGIO, J. A.; FURLANI, A. M. C. Campinas: IAC, 285 p. (Boletim técnico, 100).

CONAB, 2015. Companhia Nacional de Abastecimento. Avaliação da safra agrícola 2015/2016: primeiro levantamento $\quad-\quad$ outubro/2015. Brasília: Available 
at:<http://www.conab.gov.br/OlalaCMS/uploads/arquivos/15_10_09_17_45_57_boletim_gra os_outubro_2015_novo.pdf> Access in: 12 out. 2015.

DI DOMENICO, A. S.; DANNER, M. A.; BUSSO, C.; CHRIST, D.; COELHO, S. R. M. 2015. Análise de trilha da contaminação por aflatoxinas em grãos de milho armazenados. Pesquisa Agropecuária Brasileira, Brasília, v.50, n.6, p.441-449.

EMBRAPA, 2013 - Empresa Brasileira de Pesquisa Agropecuária. Centro Nacional de Pesquisa de Solos. Sistema Brasileiro de Classificação de Solos. 3.ed. Brasília: EMBRAPA, 353p.

FIGUEIREDO, A. S. T.; RESENDE, J. T. V. de; MORALES, R. G. F.; DIEGO, L. M.; RIZZARDI, A. 2013. Influência da umidade de grãos de trigo sobre as perdas qualitativas e quantitativas durante a colheita mecanizada. Ambiência, Guarapuava, v. 9, n.2, p. 349-357.

GOTTARDO, F. A.; CESTARI JÚNIOR, H. 2008. Viabilidade econômico-financeira de implantação de um sistema de armazenagem de grãos: um estudo de caso em uma média propriedade rural em Campo Mourão - PR. Revista em Agronegócios e Meio Ambiente, Maringá, v.1, n.1, p. 55-76.

HOLTZ, V.; REIS, E. F. dos. 2013. Perdas na colheita mecanizada de soja: uma análise quantitativa e qualitativa. Revista Ceres, Viçosa, v. 60, n.3, p. 347-353.

IGNÁCIO, V. L.; NAVA, I. A.; MALAVASI, M. M. GRIS, E. P. 2015. Influence of foliar fertilization with manganese on germination, vigor and storage time of RR soybean seeds. Revista Ceres, Viçosa, v. 62, n.5, p. 446-452.

JANAS, S.; BOUTRY, S.; MALUMBA, P.; VANDER ELST, L.; BÉRA, F. 2010. Modelling dehydration and quality degradation of maize during fluidized-bed drying. Journal of Food Engineering, Madison, v.100, n.3, p.527-534.

MAGAlHÃES, S. C.; OLIVEIRA, B. C.; TOLEDO, A.; TABILE, R. A.; SIlVA, R. P. 2009. Perdas quantitativas na colheita mecanizada de soja em diferentes condições operacionais de duas colhedoras. Bioscience Journal, Uberlândia, v.25, n.5, p.43-48.

MARQUES, O. J; DALPASQUALE, V. A; VIDIGAL FILHO, P. S; SCAPIM, C. A; RECHE, D. L. 2011. Danos mecânicos em grãos de híbridos comerciais de milho em função da umidade de colheita. Semina: Ciências Agrárias, Londrina, v.32, n.2, p.565-576.

MARQUES, O. J; VIDIGAL FILHO, P. S; DALPASQUALE, V. A; SCAPIM, C. A; PRICINOTTO, R. F.; JÚNIOR, M. M. 2009. Incidência fúngica e contaminações por micotoxinas em grãos de híbridos comerciais de milho em função da umidade de colheita. Acta Scientiarum. Agronomy, Maringá, v.31, n.4, p.667-675.

RAIJ, B. Van; ANDRADE, J. C.; CANTARELLA, H.; QUAGGIO, J. A. 2001. Análise química para avaliação da fertilidade de solos tropicais. Campinas: IAC, 285p.

SCHANOSKI, R.; RIGHI, E. Z.; WERNER, V. Perdas na colheita mecanizada de soja (Glycine max) no município de Maripá - PR. 2011. Revista Brasileira de Engenharia Agrícola e Ambiental, Campina Grande, v. 15, n. 11, p. 1206-1211.

SCHUH, G.; GOTTARDI, R.; FERRARI FILHO, E.; ANTUNES, L. E. G.; DIONELLO, R.G. 2011. Efeitos de dois métodos de secagem sobre a qualidade físico-química de grãos de milho safrinha-RS, armazenados por 6 meses. Semina: Ciências Agrárias, Londrina, v.32, n.1, p. 235-244.

SMANIOTTO, T. A.; RESENDE, O.; MARÇAL, K. A. F.; OLIVEIRA, D. E. C.; SIMON, G. A. 2014. Qualidade fisiológica das sementes de soja armazenadas em diferentes condições. Revista Brasileira de Engenharia Agrícola e Ambiental, Campina Grande, v.18, n.4, p.446453. 
TEFERA, T.; KANAMPIU, F.; DE GROOTE, H.; HELlIN, J.; MUGO, S.; KIMENJU, S.; BEYENE, Y.; BODDUPALLI, P. M.; SHIFERAW, B.; BANZIGER, M. 2011. The metal silo: An effective grain storage technology for reducing post-harvest insect and pathogen losses in maize while improving smallholder farmers' food security in developing countries. Crop Protection, London, v. 30, n.3, p. 240-245.

TOLEDO, A.; TABILE, R. A.; SILVA, R.P.; FURLANI, C. E. A.; MAGALHÃES, S. C.; COSTA, B. 2008. Caracterização das perdas e distribuição de cobertura vegetal em colheita mecanizada de soja. Engenharia Agrícola, Jaboticabal, v. 28, n.4, p. 710-719.

WEINBERG, Z. G.; YAN, Y.; CHEN, Y.; FINKELMAN, S.; ASHBELL, G.; NAVARRO, S. 2008. The effect of moisture level on high-moisture maize (Zea mays L.) under hermetic storage conditions-in vitro studies. Journal of Stored Products Research, Oxford, v.44, n.2, p.136-144. 